ICHNEUMON RUFIVENTRIS Brullé.

Two specimens of this handsome ichneumon were bred late in July i 884 , from the chrysalids of Pyrameis cardui, the insects emerging as noted by $\mathrm{Mr}$.
Hart "by cutting a lid from the anterior end of the pupa." Other specimens were collected in Tazewell Co. during May, I88I, and in Union Co. I4 July I 880 and 14 Sept. I883.

\title{
IDENTIFICATION OF THE NOTODONTIAN GENUS SCHIZURA OF DOUBLEDAY.
}

BY ALPHEUS SPRING PACKARD, PROVIDENCE, R. I.

In The entomologist for Feb. I84r, Edward Doubleday, in an article entitled, "Characters of three new genera of notodontidae from North America," describes and figures Schizura ipomeae giving the generic and specific characters in some detail, and illustrating, in a plate facing p. 6o, the larva and pupa from manuscript drawings by John Abbot.

When preparing the manuscript of a monograph of the bombycidae, which was published in abstract under the name, "Synopsis of the bombycidae of the United States" (Proc. Entom. soc. Phil., s864, v. 3, p. 97-130, 33-1-396), I was unable with certainty to identify the genus (the species not then being known to occur north of Florida), but placed it next to my genus Coelodasys. In 1855 Walker referred it to Heterocampa; but neither Mr. Grote nor Mr. H. Edwards have been able to identify it. While looking over, during the past winter, the volume of manuscript colored drawings by John Abbot, in the library of the Boston society of natural history, I found the original colored drawing, copied by Doubleday and described by him as the larva of Schizura ipomeae. The larva figured by Abbot I recognized as that of Coelodasys biguttatus Pack. which I reared last summer in all its stages from eggs kindly sent me by Miss Emily A. Morton, of Newburgh, N. Y.

On comparing my specimen of $C$. biguttatus with Doubleday's description both of the generic and specific characters, it agrees exactly, and leaves no doubt but that my genus Coelodasys is a synonym of Doubleday's Schizura. Hence the former name should be dropped and that of Schizura retained, and $C$. biguttatus should, with little doubt, be regarded as a synonym of $S$. ipomeae. Of Coelodasys I described also C. edmandsii and C. harrisii, besides referring Notodonta unicornis to it. My C. cinercofrons, as previously shown by Grote, is a melanitic variety of $C$. biguttatus. All these species which are valid should, then, be referred to Schizura.

I may also add that I have identified Doubleday's Heterocampa astarte, as Grote had previously done: the larva is represented by Doubleday's fig. I, the pupa by his fig. 2. His Lochmaeus manteo I have also readily identified; Grote's Heterocampa subalbicans is a synonym of it. Doubleday's unnamed larva, figs. 3 and 5 , is that of Walker's Cecrita guttivitta, referred by Grote so Heterocampa, and which I have teen in its early and imago stages in Prof. Riley's collection, having also collected the caterpillar myself either. in Rhode Island or Maine. 

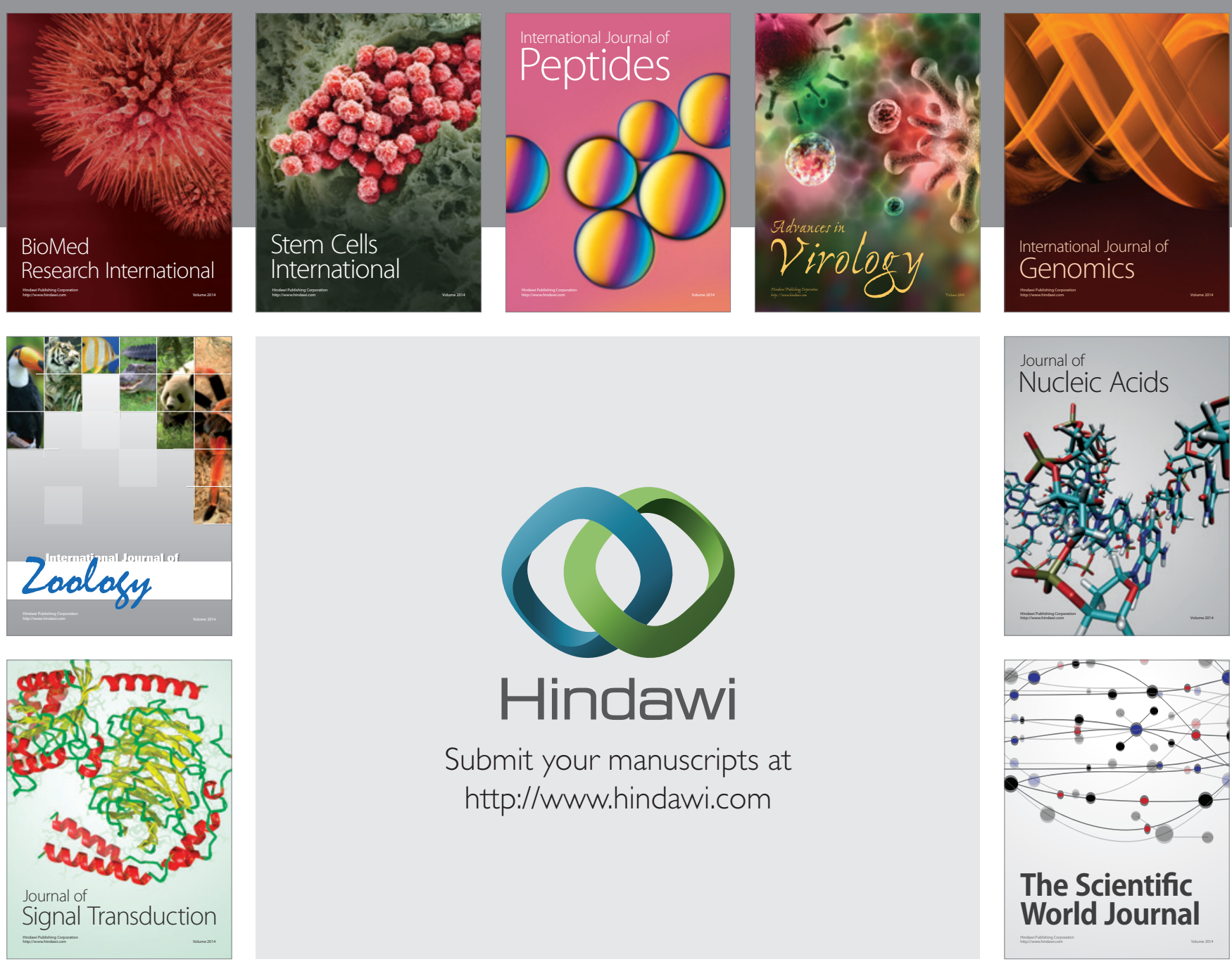

Submit your manuscripts at

http://www.hindawi.com
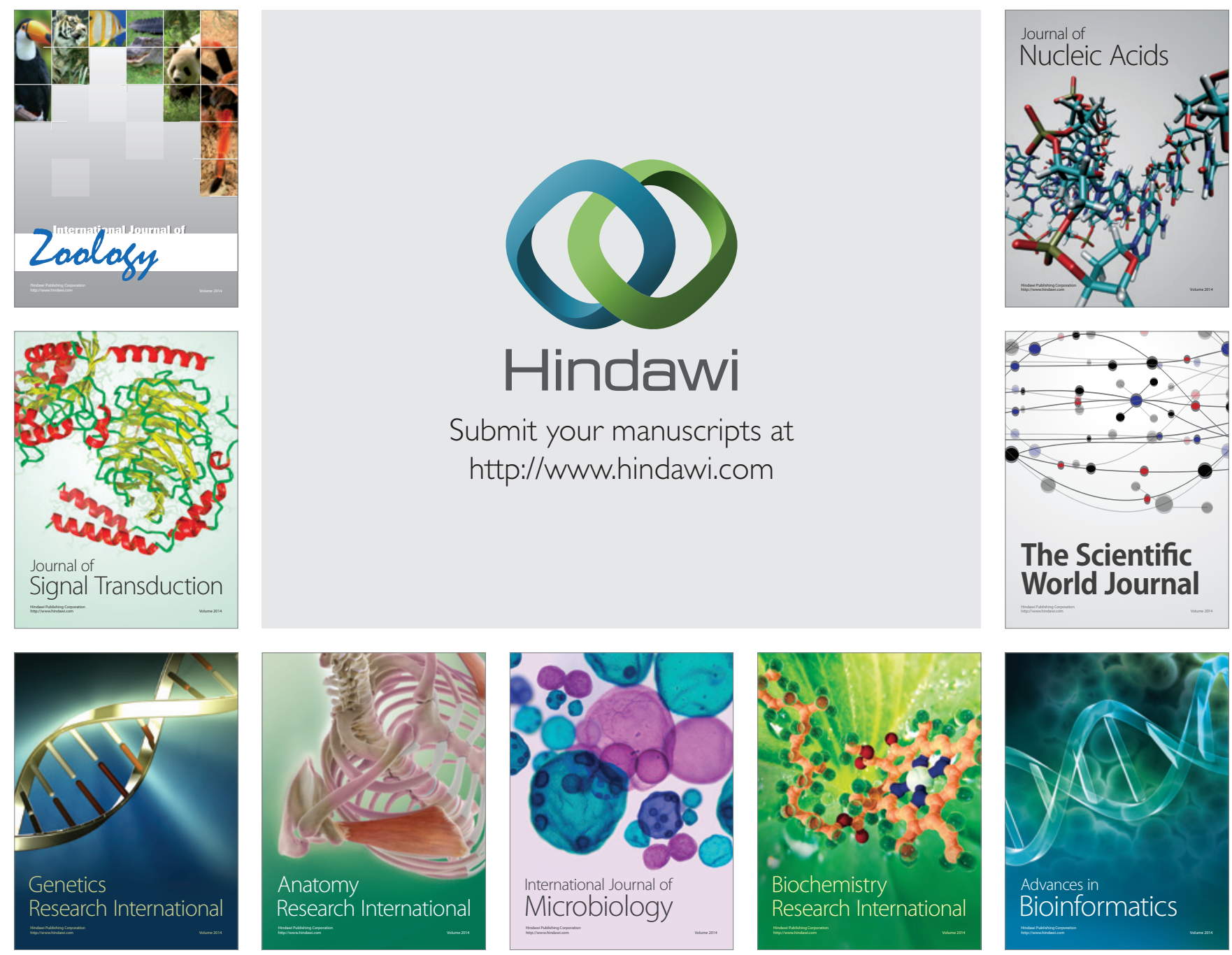

The Scientific World Journal
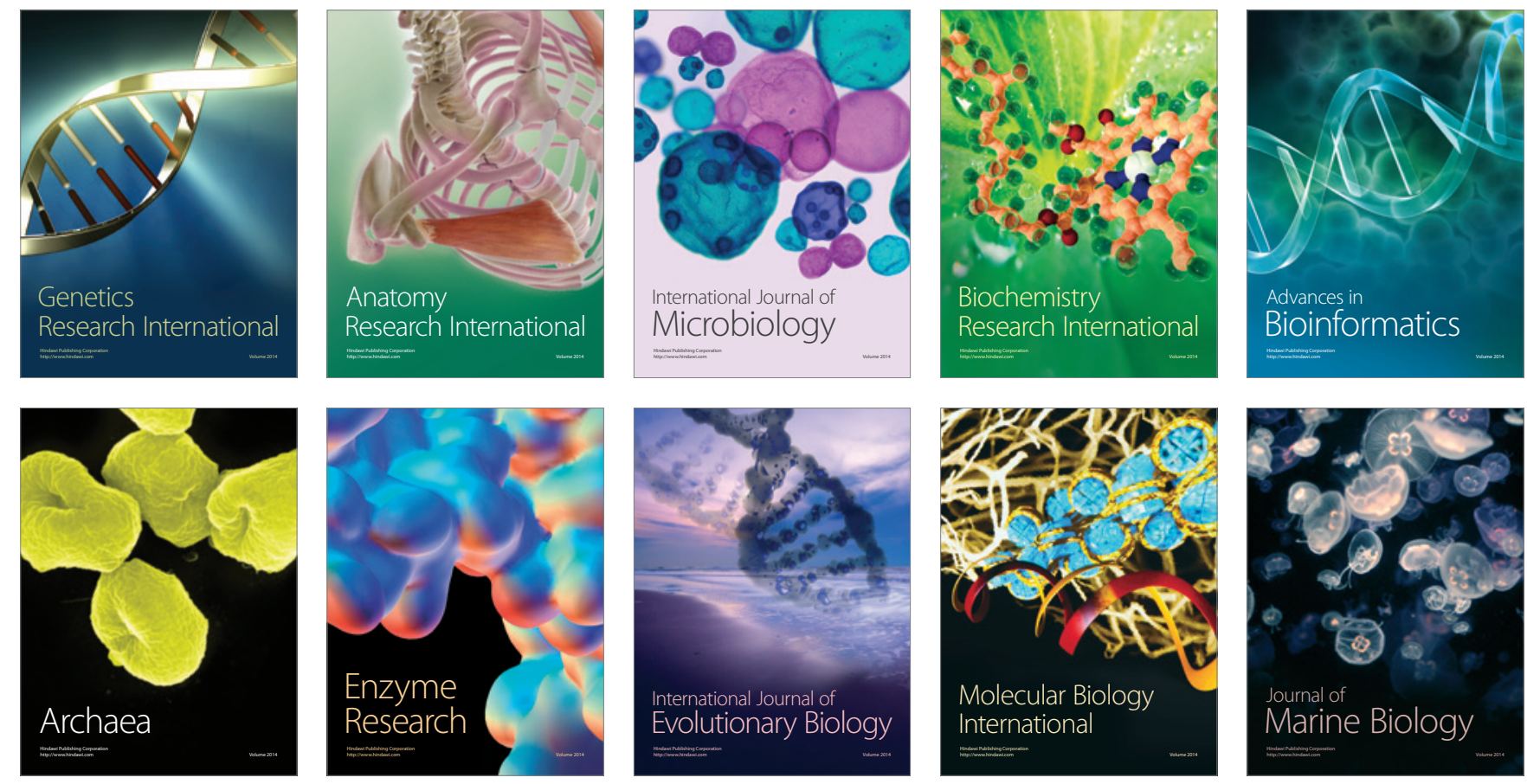